\title{
IMPORTANCE OF ACUTE CARDIAC CARE REGISTRIES AT THE NATIONAL LEVEL
}

\author{
Ana Đuzel, Marin Pavlov and Zdravko Babić
}

Sestre milosrdnice University Hospital Centre, Zagreb, Croatia

\begin{abstract}
SUMMARY - Improving organization and patient care quality in intensive care units is increasingly important as intensive care unit diagnostic and therapeutic procedures account for a growing proportion of hospital services. We identified the lack of comprehensive national and international registries available in the contemporary literature. This paper aims to describe and analyze cardiac intensive care unit (CICU) network at the national level in Croatia and its comparison with more developed countries. Thirty-four representatives from all Croatian acute hospitals (response rate of $100 \%$ ) filled in a web based questionnaire on CICU organization and competence during September and October 2016. Organization and available technical procedures for health care in general, and especially in very expensive CICU treatment, highly depends on gross domestic product (GDP) per capita. That is why one could expect that Croatia, with the second lowest GDP among European Union countries and $4.7 \mathrm{CICU}$ per million inhabitants will have worse results in this field in comparison with most of these countries. Results such as one nurse responsible for a mean of $2.7 \mathrm{CICU}$ patients, $52 \%$ of cardiologists among physicians during working hours but $37 \%$ during night shifts, $24 / 7$ transesophageal echocardiography in only $26.5 \%$ of CICUs, one-third without therapeutic hypothermia, and $23.5 \%$ without extracorporeal membrane oxygenation treatment are some of these results, revealing much room for improvement. This representative, nationwide sample of Croatian CICUs also demonstrated considerable variation of key elements of structures with respect to hospital size, academic status and financial issues, as well as a trend towards current guidelines. This kind of investigation is very important for proposing standards, reimbursement master plan, or quality assessment of the national health system.
\end{abstract}

Key words: Intensive cardiac care; Cardiology; Registry; Heart; Questionnaire

\section{Introduction}

Intensive care unit (ICU) and cardiac intensive care unit (CICU) are dedicated to critical medical care, defined as the diagnosis and management of acute lifethreatening conditions treated by specifically trained health professionals. Two major advances in management followed by distinctive changes in the organization of CICU have been described ${ }^{1}$, and attributed to early invasive strategy for treating acute coronary syndromes, but also rapid aging of the population. In the

Correspondence to: Ana Đuzel, $M D$, Sestre milosrdnice University Hospital Centre, Vinogradska c. 29, HR-10000 Zagreb, Croatia E-mail: ana29.djuzel@gmail.com

Received May 7, 2018, accepted December 24, 2019 next near half-decade, another paper recognized an increased demand for cardiovascular critical care ${ }^{2}$. A meta-analysis of 13 non-randomized studies showed that ICUs managed by intensive care specialists provided superior outcomes, resulting in a reduced length of stay ${ }^{3}$, reduced length of mechanical ventilation ${ }^{4}$ and associated costs, and finally, reduced mortality ${ }^{5-7}$. In these studies, mandatory intensivist consultation or a closed ICU was superior to low-intensity staffing, defined as no intensivist or elective intensivist consultation ${ }^{8}$. Also, adding a trained intensivist in a community teaching hospital was temporally associated with improved clinical and educational outcomes in that type of hospital'.

According to Morrow et al. ${ }^{2}$, we have been witnessing evolution of CICU from point of rapid resuscita- 


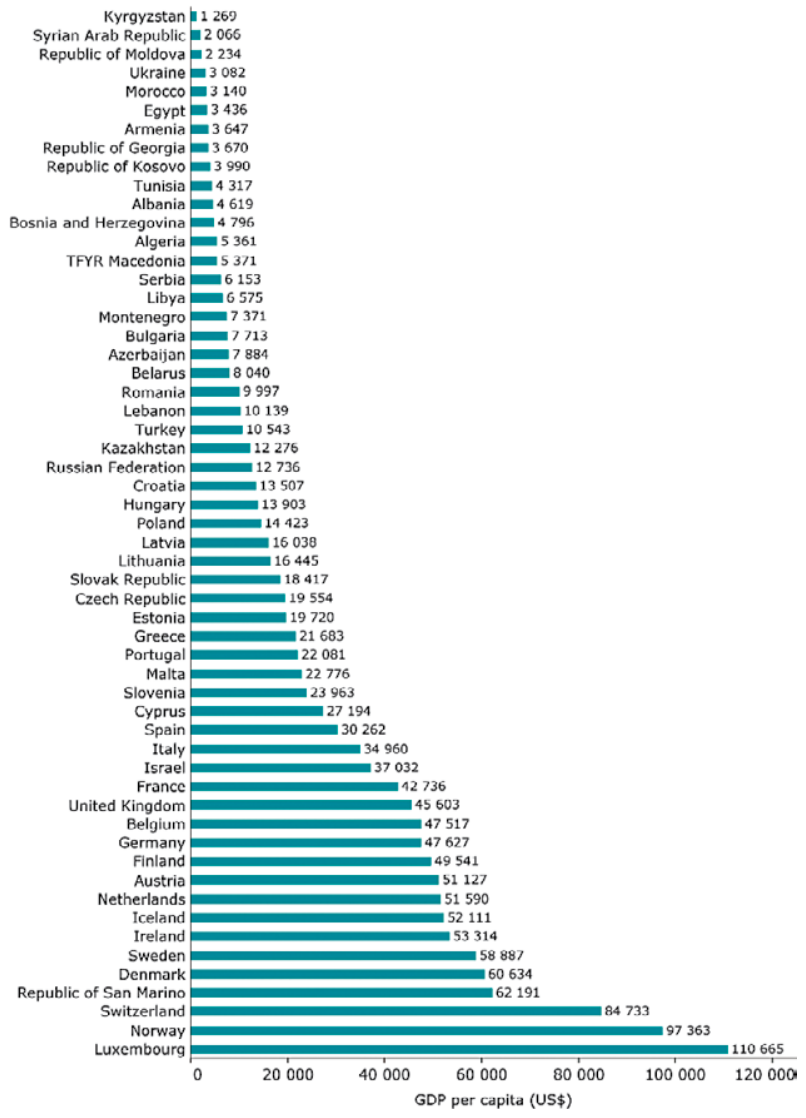

Fig. 1. Gross domestic product per capita (US dollars) 2014 or latest year, ESC member countries. ESC Atlas of Cardiology based on data from the World Bank (WB); http://data.worldbank.org/indicator.

tion to preventive intervention, and finally comprehensive critical care. The same authors made a proposal for categorization of CICU, ranging from level 1 as the highest to level 3 as the lowest category. A level 1 CICU has all forms of invasive and noninvasive monitoring capabilities, and advanced technologies, management of patients with refractory shock or resuscitated cardiac arrest by full-time intensivists, either cardiac intensivists or general intensivists working collaboratively with cardiologists, nurse-to-patient ratios $1: 1$ or $1: 2$, and access to interventional cardiology and cardiac surgical support. A level $1 \mathrm{CICU}$ would be the likely paradigm for most large tertiary medical centers. A level 2 CICU is capable of providing initial evaluation and management of most acute cardiovascular conditions, all invasive and noninvasive monitoring is available, but mechanical hemodynamic support is limited to non-ventricular assist devices. Management
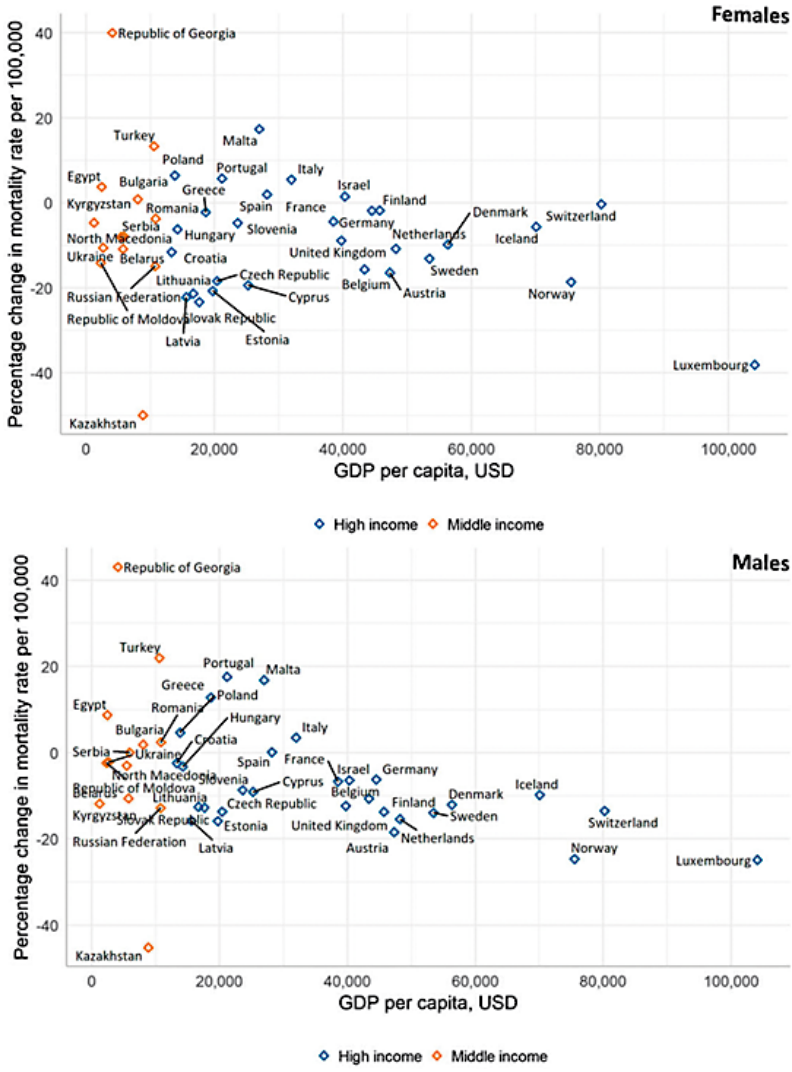

Fig. 2. Change in cardiovascular disease crude mortality rates between 2010 and latest year available among females and males aged <70years in ESC member countries vs. GDP per capita (US\$, 2017). According to European Society of Cardiology: Cardiovascular Disease Statistics 2019 European Heart Journal, ehz859, https:// doi.org/10.1093/eurheartj/ehz859.

is generally by cardiologist, but the unit may be combined with a general medical or surgical ICU, and nurse-to-patient ratios are usually 1:1 to 1:3. A level 3 $\mathrm{CICU}$ has capacity to manage respiratory failure, administer vasopressors and inotropes for hypotension but may be focused on the care of patients with suspected acute coronary syndrome, heart failure without shock, and hemodynamically stable arrhythmias. A level 3, like level 2, may also be combined with a general medical ICU. Invasive monitoring and mechanical hemodynamic support are not usually provided in this unit, and nurse-to-patient ratios are usually 1:2 to 1:3.

In summary, critical care costs are expected only to rise because of the development of new technologies, including complex modes of mechanical ventilation, invasive hemodynamic monitoring tools, induction of 
therapeutic hypothermia, renal replacement therapies, bedside vascular procedures with imaging guidance, and mechanical circulatory support. New technologies are also an answer to the rising prevalence of non-cardiovascular diagnoses including sepsis, acute kidney injury, and respiratory failure ${ }^{10}$. ICUs have been a center of interest concerning quality assessment, given the high mortality rate, potential for iatrogenic complications, and increased resource utilization. Quality assessment initiatives in the ICU have traditionally focused on outcomes, particularly on mortality rates. Nevertheless, in order to investigate outcomes, it is crucial to implement evaluation of structure (organization), and process (health care delivery), and this was the main reason for us to engage in this research. Surveys with questionnaires play a crucial role in policy making ${ }^{11}$, in addition to the states described by Markov processes.

The gross domestic product (GDP) per capita is one of the standard indicators of financial development. There is considerable diversity of national resources across Europe; GDP per capita ranges from $<\$ 4000$ in some Eastern European countries to $>\$ 40000$ in the West $^{12}$ (Fig. 1). Political and organizational aspects of health care show similar variation, the net result being huge disparities in the population cardiovascular disease (CVD) risks and the resources available for prevention and treatment.

Acute cardiac care conditions in Croatia are usually diagnosed in out-of-hospital setting by emergency doctors or less often by general practitioners, and in hospital emergency departments and ambulances. All patients with acute cardiac conditions are urgently hospitalized in the nearest hospital. The Croatian primary percutaneous coronary intervention (PCI) network was introduced earlier ${ }^{13,14}$, and showed a growing trend of 540-550 patients with acute ST-segment elevation myocardial infarction (STEMI) per million inhabitants. Each of the eleven PCI centers in Croatia with $24 / 7$ work schedule had a catchment population of 384,000 inhabitants, approaching the number of at least 600 primary PCIs per million inhabitants. On the contrary, we found that only 380-390 non-ST-segment elevation myocardial infarction (NSTEMI) patients per million inhabitants received PCI in the first 72 hours $^{15}$. Croatia has achieved a decreasing mortality trend in coronary heart disease, as well as in the overall cardiovascular pathology in the past ten years $(53 \%$ vs. 47\%). Even though we have witnessed significant improvement in cardiovascular mortality in the previous decade, Croatia is still positioned among European countries with high cardiovascular mortality. According to the newest European Society of Cardiology: Cardiovascular Disease Statistics 2019 that includes trends in CVD crude mortality rates between 2010 and the latest year available, there still is room for significant improvement (Fig. 2). Acute cardiac care conditions are reimbursed by the National Health System based on obligatory health insurance of all employed persons, but also retired and unemployed (the latter paid by state). Quoted per patient reimbursement with a system of flat rate packages built from pre-established lists of pathologies, technical interventions and some comorbidities are also used in Croatia. Croatia belongs to the group of transition countries, and to the best of our knowledge, observational studies involving organization of acute cardiac care have not been systematically reviewed in this kind of setting. We compared CICU and ICU of this economically less developed European country with developed European countries.

\section{Patients, Materials and Methods}

During September and October 2016, we conducted an online questionnaire involving all 34 Croatian acute hospitals. We promoted and distributed a national web-based survey in 34 CICUs, either strictly cardiac ICU or combined with other internal medicine fields or anesthesiology ICU. We developed two types of questionnaire depending on the type of ward (only cardiac/internal medicine patients or combined cardiac/internal medicine/anesthesiology unit). The first type of questionnaire contained 17 items and the second one contained 15 items. Questions were either binary or multiple-choice. In addition, there was a possibility of making comments at the end of the questionnaire. E-mail addresses were obtained from the National Cardiac Care Society and the questionnaire was sent to chief physicians of CICUs in Croatia. Percentages reported are proportions of responses and Fisher exact test was used to calculate p-values for categorical data. Statistical significance was set at $\mathrm{p}<0.05$.

\section{Results}

Our investigation included all Croatian acute hospitals (local, regional and tertiary level hospitals) and 


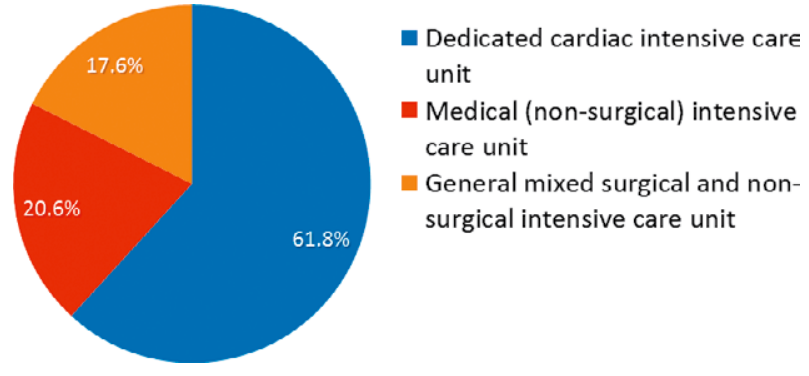

Fig. 3. Types of intensive care units.

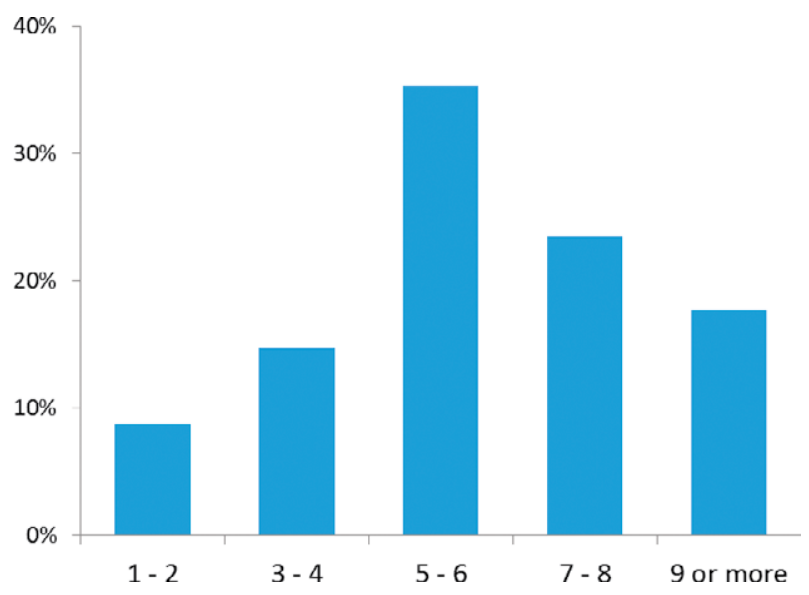

Fig. 4. Number of cardiac intensive care unit beds.

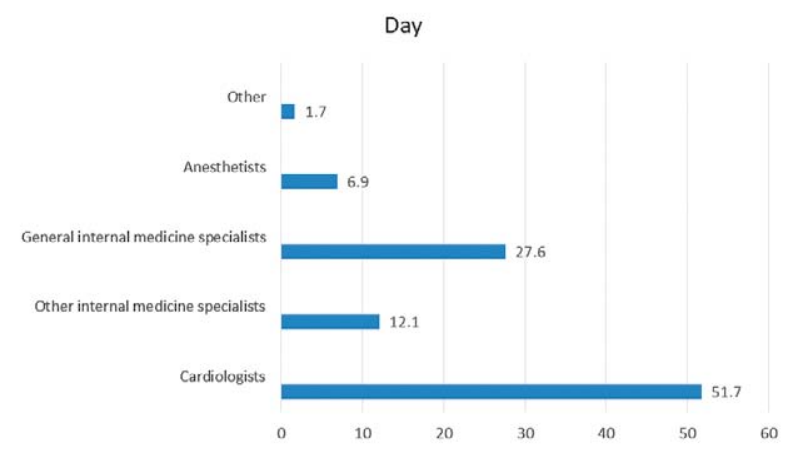

the response rate was $100 \%$ (34 of 34). The majority of participating centers $(61.8 \%)$ were dedicated CICU, $20.6 \%$ were non-surgical internal medicine ICUs, and the rest were general mixed surgical and non-surgical ICUs (Fig. 3). Croatia has 4.7 CICUs per million inhabitants. More than one-third of Croatian ICUs had 5 or 6 cardiac beds, almost one-fourth had 7 or 8 beds, and the others ranged widely from 1 to 9 or more beds (Fig. 4). Cardiologists formed the majority of physicians during working hours in these departments, but to a lesser extent during night shifts (Fig. 5). Almost two-thirds of investigated ICUs had less than 4 beds per physician and at least $85 \%$ of investigated ICUs had 3 or less beds per nurse (Fig. 6). Average number of hospital admissions per year is shown in Figure 7. We found that 24/7 transthoracic echocardiography (TTE) was available in $76.5 \%$ of ICUs, whilst only $26.5 \%$ of ICUs provided 24/7 transesophageal echocardiography (TEE) (Fig. 8).

Among services that were consistently used were primary PCI, where all acute hospitals urgently transferred STEMI/high risk NSTEMI patients to PCI centers, or performed PCI themselves. Additionally, $50 \%$ of patients requiring intra-aortic balloon pump

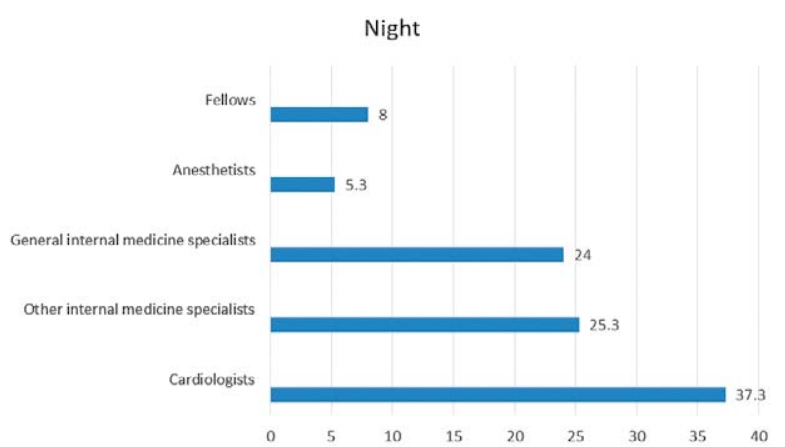

Fig. 5. Percentage of specialists during working hours and night shifts.

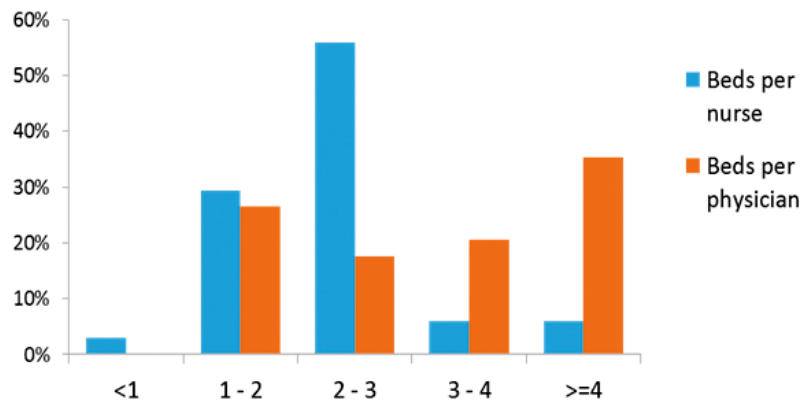

Fig. 6. Number of beds per nurse and physician during working hours. were transferred to other hospitals. Dialysis was performed in $90 \%$ of investigated units, in $29 \%$ of them without help from nephrologists. Mechanical ventilation was performed in almost $60 \%$ of centers without help from other specialists, and in only one hospital, these patients were transferred to another hospital (Fig. 9). With regard to other specific forms of intensive treatment, Croatian hospitals showed large differences. Even though more than one-fourth performed therapeutic hypothermia alone or with the help of other specialists, one-third of Croatian centers did not 
implement hypothermia, and other centers transferred patients to other hospitals or other departments in their hospitals. Extracorporeal membrane oxygenation $(\mathrm{ECMO})$ is predominantly a multidisciplinary proce-

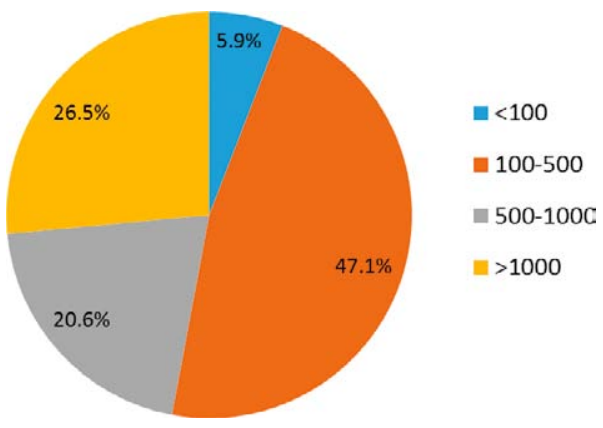

Fig. 7. Total number of admissions per year.

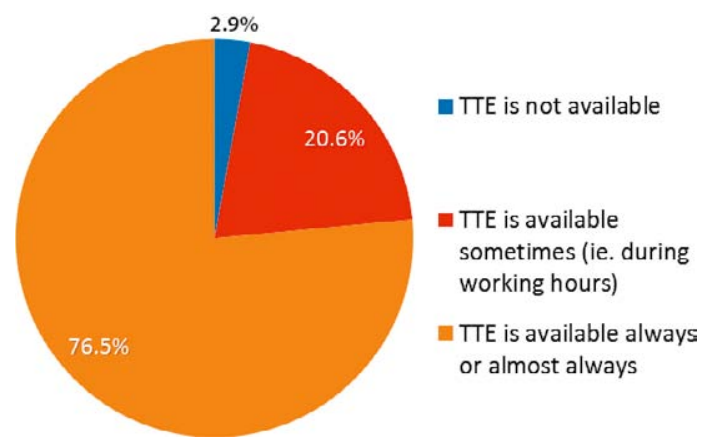

dure, in Croatia reserved for large academic hospitals, with two exceptions.

\section{Discussion}

According to this and other investigations ${ }^{15}$, there is a respectable access to tertiary hospitals for urgent cardiac patients in Croatia. Tertiary hospitals are distributed across all Croatian regions and coupled with the nearest regional and county hospitals in the organizational network. Local policies on referral and selection criteria generally do not differ among Croatian regions and reflect concordance with clinical guidelines. In order to take a more realistic view on the state-of-the-art, comparison with other countries according to development of economy is crucial. Many

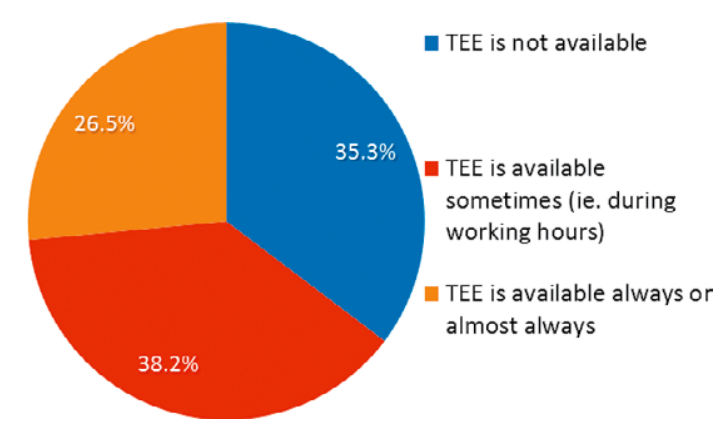

Fig. 8. Transthoracic echocardiography (TTE) and transesophageal echocardiography (TEE) availability.

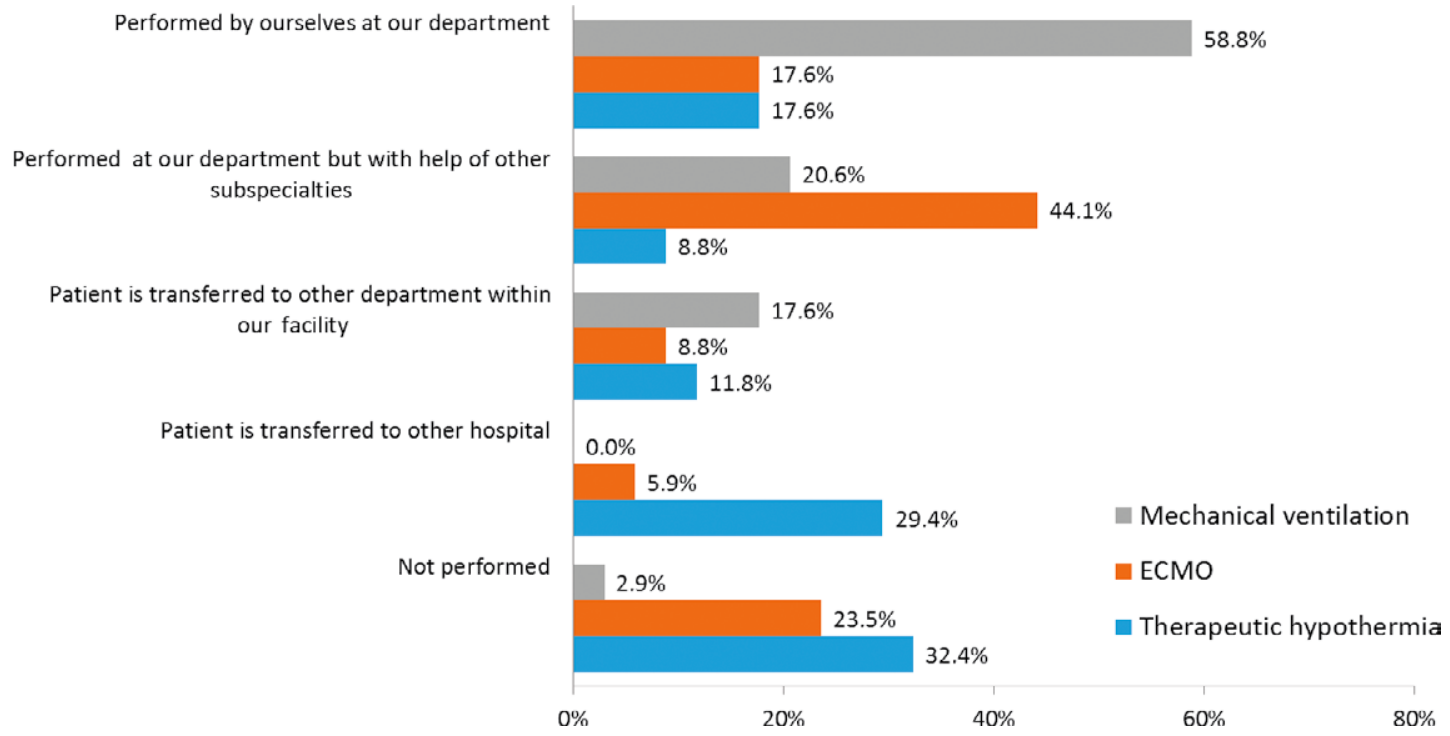

Fig. 9. Technical procedures in acute cardiac care.

$\mathrm{ECMO}=$ extracorporeal membrane oxygenation 
studies suggest that outcome of ICU treated patient is related to the number of ICU beds or number of $\mathrm{pa}^{-}$ tients treated. An interesting retrospective cohort study demonstrated that both hospital volume of ICU patients and ICU to hospital bed ratio were significantly associated with mortality ${ }^{16}$. The number of ICU beds in two large Canadian jurisdictions is comparable to those found in this investigation, and so is the nurse to patient ratio $^{17}$. Another international, multicenter, observational study found that a nurse to patient ratio of less than 1:1.5 was independently associated with a lower risk of in-hospital death ${ }^{18}$. This ratio was achieved in less than one-third of the ICUs investigated in this survey. A nationwide analysis of ICUs in Germany showed that the mean number of beds per ICU was 10.4, with significant differences depending on hospital size ${ }^{19}$. Our investigation revealed less sized ICUs on average. In a German study, $81 \%$ of the ICUs provided around-the-clock physician presence (range: 66\%-98\%). We identified 100\% physician around-theclock presence, however, emphasizing that a significant percentage of non-cardiologists during night shifts is of utmost importance, reflecting low availability of cardiologists, especially in smaller hospitals. In addition, our results indicated physician heterogeneity during night shifts, which reflects the obvious need for a greater number of cardiologists. Shift-wise, one nurse was responsible for a mean of 2.7 patients (morning $1: 2.3$, afternoon $1: 2.6$, night 1:3.3 patients) with significant variation according to hospital size (smaller hospitals 1:2.9, university hospitals 1:2.1; $\mathrm{p}<0.001$ ). Interesting results of a survey in Germany showed an increase in interdisciplinary ICUs (74\%), and a divergent trend in human resource development with an increase of physicians and decrease of nurses ${ }^{20} . \mathrm{A} \mathrm{Eu}-$ ropean survey from 1998 found that at that time, 67\% of the ICUs had between 6 and 12 beds, and 54\% were mixed medical-surgical units. Among British units, $79 \%$ had more than three full-time nursing equivalents per ICU bed, while in Sweden $75 \%$ of units had less than two full-time nursing equivalents per ICU bed $^{21}$.

Croatia has 4.7 CICUs per million inhabitants with a range of 1-9 (mostly 5-6) beds. A more precise and contemporary population-based cross-sectional study established the overall age- and gender-standardized number of ICU patients per 1000 personyears for the 5 -year period. The result was 4.3 patients ranging from 3.7 to 5.1 patients per 1000 person-years in five regions of Denmark and from 2.8 to $23.1 \mathrm{pa}-$ tients per 1000 person-years in 98 municipalities ${ }^{22}$. We recognized the need for a similar study in Croatia for more precise comparison.

According to most studies, TTE was widely available in ICU, but in one study from Switzerland it was not routinely used, and in most cases, TTE was not performed by intensive care specialists ${ }^{23}$. Our study showed that TTE was performed not only by intensivists but often by internal medicine specialists. By far most experience in the use of TEE in CICU stems from critical care units with a high proportion of cardiac, including coronary and/or cardiac surgical patients (53\%). Given this heterogeneity of settings, it is not unusual to find the reported findings to vary considerably ${ }^{24}$. To the best of our knowledge, although the present body of evidence supporting the use of TEE lacks prospective, randomized controlled studies, current evidence, as well as clinical experience points to the significant benefits gained by the availability of TEE in CICUs. To conclude, CICUs in Croatia with $26.5 \%$ around-the-clock availability emphasize the need for systematic training among physicians and staff.

According to Danish Heart Registry, the number of primary PCI during the last ten years ranged between 1200 and 1300 per million inhabitants ${ }^{25}$, and there were 7650 coronary angiographies for NSTE$\mathrm{MI} / \mathrm{unstable}$ angina pectoris indication. The figure of almost 600 primary PCIs per million inhabitants positioned Croatia along the most developed European economies. On the contrary, with only 380-390 NSTEMI patients per million inhabitants receiving $\mathrm{PCI}$ in the first 72 hours, we recognize much room for improvement.

An Italian ICU survey from 2013 showed that therapeutic hypothermia was still underused (55.1\%), however, with a significant increase in the adoption of hypothermia in the past 5 years $^{26}$. The use of target temperature management after cardiac arrest has been introduced in most of the German ICUs ${ }^{27}$. These results do not correlate with ours (only 26.4\%) and more efforts should be invested to increase the utility of this method.

Extracorporeal membrane oxygenation, either supporting gas exchange or hemodynamics in patients with severe respiratory or cardiac failure, has shown 
considerable evolution over the last decade, with a constant rise since 2009 in the number of ECMOtreated patients and number of centers providing ECMO support. In addition, a growing amount of evidence on treating such patients ${ }^{28}$ provides better treatment and care.

Scottish adult cardiothoracic surgical services are provided by three ECMO regional centers covering a population of 5.2 million individuals and achieving acceptable functional recovery despite a significant complication rate ${ }^{29}$. According to our best knowledge, there is only one study ${ }^{30}$ to show recent epidemiological data of ECMO utilization and associated mortality in a high-income country. Although mortality decreased with increasing experience, it has remained high in both venovenous and venoarterial ECMO. In a high-income country such as Germany, the use of ECMO has been rapidly increasing since 2007 for both respiratory and cardiac support, from 0.1:100,000 in 2007 to $0.7: 100,000$ in 2012, and to a maximum of 3.5:100,000 in 2014 for cardiac support. Since the introduction of ECMO program in Croatia in 2008, there is a positive trend of its utilization rates, but according to our investigation data, $23.5 \%$ of ICUs do not use ECMO and do not transfer patients with indication for ECMO to other centers with the possibility of such treatment.

A questionnaire developed in adult ICUs in Switzerland found that overall utilization rate for noninvasive ventilation (NIV) was $26 \%$ of all mechanical ventilations, also showing that the preferred location of NIV initiation in the acute hospital was the ICU (86\%), not the emergency department ${ }^{31}$. We showed that only one ICU did not implement this method.

Online survey in the UK revealed that a nephrologist was never or rarely consulted about patients with acute renal injury in over $40 \%$ of the units. Continuous renal replacement therapy was managed almost exclusively by intensivists, while intermittent hemodialysis was managed predominantly by nephrologists ${ }^{32}$. In our study, nine of ten ICUs provided hemodialysis and one of three without the help from nephrologists.

Future research should focus on additional elements of health care organization. Comprehensive staffing models evaluating all staff involved may be one approach. Another approach may be to evaluate other factors such as adherence to new evidence-based practices or processes (for example, therapeutic hypother- mia, ECMO). If these procedures are evaluated as effective also in real-world studies and registries, then all hospitals should be able to implement similar models of treatment in daily routine. Structures in intensive care medicine comprise human, as well as material resources, organization and management, which are related to processes thereby affecting patient outcomes.

In conclusion, this representative, nationwide sample of Croatian CICUs demonstrated considerable variation of key elements of structures with respect to hospital size, but also a trend towards current guidelines. However, we can conclude that our clinical practice offers room for improvement in this field, which will be tightly associated with the country's financial capabilities. Results of this kind of investigation have to be taken into account when proposing standards, reimbursement plan, development, or quality assessment of CICU network.

\section{References}

1. Hasin Y, Danchin N, Filippatos GS, Heras M, Janssens U, Leor J, et al. Recommendations for the structure, organization, and operation of intensive cardiac care units. Eur Heart J. 2005;26(16):1676-82. doi: 10.1093/eurheartj/ehi202.

2. Morrow DA, Fang JC, Fintel DJ, Granger CB, Katz JN, Kushner FG, et al. Evolution of critical care cardiology: transformation of the cardiovascular intensive care unit and the emerging need for new medical staffing and training models: a scientific statement from the American Heart Association. Circulation. 2012:1408-28. doi: 10.1161/CIR.0b013e31826890b0.

3. Dimick JB, Cattaneo SM, Lipsett PA, Provonost PJ, Heitmiller RF. Hospital volume is related to clinical and economic outcomes of esophageal resection in Maryland. Ann Thorac Surg. 2012;72(2):334-40. doi: 10.1016/s0003-4975(01)02781-3.

4. Multz A, Chalfin D, Samson IM, Dantzker DR, Fein AM, Steinberg HN, et al. A closed medical intensive care unit improves resource utilization when compared with an open MICU. Am J Respir Crit Care Med. 1998;157:1468-73. doi: 10.1164/ajrccm.157.5.9708039.

5. Provonost PJ, Angus DC, Dorman T. Physician staffing patterns. JAMA. 2002;288(17):2151-62. doi: 10.1001/ jama.288.17.2151.

6. Reynolds HN, Haupt MT, Thill-Baharozian MC, Carlson RW. Impact of critical care physician staffing on patients with septic shock in a university hospital medical intensive care unit. JAMA. 1988;260(23):3446-50.

7. Li TCM, Phillips MC, Shaw L, Cook EF, Natanson C, Goldman L. On-site physician staffing in a community hospital intensive care unit impact on test and procedure use and on patient outcome. JAMA. 1984;252(15):2023-7. 
8. Brown JJ, Sullivan G. Effect on ICU mortality of a full-time critical care specialist. Chest. 1989;96(1):127-9. doi: 10.1378/ chest.96.1.127.

9. Manthous CA, Amoateng-Aojepong Y, Al-Kharrat T, Jacob B, Alnuaimat HM, Chatila W, et al. Effects of a medical intensivist on patient care in a community teaching hospital. Mayo Clin Proc. 1997;72(5):391-9. doi: 10.4065/72.5.391.

10. Katz JN, Shah B, Volz E, Horton J, Shaw L, Newby L, et al. Evolution of the coronary care unit: clinical characteristics and temporal trends in healthcare delivery and outcomes. Crit Care Med.2010;38:375-81. doi: 10.1097/CCM.0b013e3181cb0a63.

11. Slattery EL, Voelker CCJ, Nussenbaum B, Rich JT, Paniello RC, Neely JG. A practical guide to surveys and questionnaires. Otolaryngol Head Neck Surg. 2011;144(6):831-7. doi: 10.1177/0194599811399724.

12. Eurostat - http://epp.eurostat.ec.europa.eu/portal/page/portal/euros.

13. Widimsky P, Wijns W, Fajadet J, de Belder M, Knot J, Aaberge L, et al. European Association for Percutaneous Cardiovascular Interventions. Reperfusion therapy for ST elevation acute myocardial infarction in Europe: description of the current situation in 30 countries. Eur Heart J. 2010;31(8):943-57. doi: 10.1093/eurheartj/ehp492.

14. Nikolić Heitzler V, Babić Z, Miličić D, Bergovec M, Raguž M, Mirat J, et al. Results of the Croatian Primary Percutaneous Coronary Intervention Network for patients with ST-segment elevation acute myocardial infarction. Am J Cardiol. 2010;105(9):1261-7. doi: 10.1016/j.amjcard.2009.12.041.

15. Babić Z, Pavlov M. Acute coronary syndrome in Croatia. Cardiol Croat. 2016;11:307-13.

16. Sasabuchi Y, Yasunaga H, Matsui H, Lefor AK, Horiguchi H, Fushimi K, Sanui M. The volume-outcome relationship in critically ill patients in relation to the ICU-to-hospital bed ratio. Crit Care Med. 2015;43(6):1239-45. doi: 10.1097/ CCM.0000000000000943.

17. Dodek PM, Norena M, Wong H, Keenan S, Martin C. Assessing the influence of intensive care unit organizational factors on outcomes in Canada.J Intensive Care Med. 2015;30(7):4139. doi: $10.1177 / 0885066614521973$.

18. Sakr Y, Moreira CL, Rhodes A, Ferguson ND, Kleinpell R, Pickkers $\mathrm{P}$, et al. Extended Prevalence of Infection in Intensive Care Study I. The impact of hospital and ICU organizational factors on outcome in critically ill patients: results from the Extended Prevalence of Infection in Intensive Care study. Crit Care Med. 2015;43:519-26. doi: 10.1097/CCM.00000 00000000754.

19. Graf J, Reinhold A, Brunkhorst FM, Ragaller M, Reinhart K, Loeffler M, et al. Variability of structures in German intensive care units - a representative, nationwide analysis. Wien Klin Wochenschr. 2010;122(19):572-8. doi: 10.1007/s00508-0101452-8.
20. Markewitz A, Trummer G, Pilarczyk K, Beckmann A. Status of cardiac surgical intensive care medicine in Germany during 2013: a report on behalf of the German Society for Thoracic and Cardiovascular Surgery. Thorac Cardiovasc Surg. 2014;62(07):536-42. doi: 10.1055/s-0034-1384803.

21. Pauwels D, Somers Y, Vincent JL. A profile of European ICU nursing. Intensive Care Med.1998;24(9):939-45. doi: 10.1007/ s001340050693.

22. Vestergaard AHS, Christiansen CF, Nielsen H. Christensen S, Johnsen SP. Geographical variation in use of intensive care: a nationwide study. Intensive Care Med. 2015;41:1895. doi: 10.1007/s00134-015-3999-3.

23. Siegenthaler N, Giraud R, Saxer T, Courvoisier DS, Romand JA, Bendjelid K. Haemodynamic monitoring in the intensive care unit: results from a web-based Swiss survey. Biomed Res Int. 2014;2014:129593. doi: 10.1155/2014/129593.

24. Hüttemann E. Transoesophageal echocardiography in critical care. Minerva Anestesiol. 2006;72:891-913.

25. Cengiz Ö, Knud J, Lassen JF, von Kappelgaard LM, Mortensen PE, Gislason G. The Danish Heart Registry. Clin Epidemiol. 2016;8:503-8. doi: 10.2147/CLEP.S99475.

26. Gasparetto N, Scarpa D, Rossi S, Persona P, Martano L, Bianchin A. Therapeutic hypothermia in Italian intensive care units after 2010 resuscitation guidelines: still a lot to do. Resuscitation. 2014;85(3):376-80. doi: 10.1016/j.resuscitation.2013. 11.014 .

27. Storm C, Meyer T, Schroeder T, Wutzler A, Jorres A, Leithner C. Use of target temperature management after cardiac arrest in Germany - a nationwide survey including 951 intensive care units. Resuscitation. 2014;85(8):1012-7. doi: 10.1016/j.resuscitation.2014.04.023.

28. Dzierba AL, Abrams D, Brodie D. Medicating patients during extracorporeal membrane oxygenation: the evidence is building. Crit Care. 2017;21(1):66. doi: 10.1186/s13054-0171644-y.

29. Khorsandi M, Dougherty S, Sinclair A, Buchan K, MacLennan F, Bouamra O, et al. A 20-year multicentre outcome analysis of salvage mechanical circulatory support for refractory cardiogenic shock after cardiac surgery. J Cardiothorac Surg. 2016;11:151. doi: 10.1186/s13019-016-0545-5.

30. Karagiannidis C, Brodie D, Strassmann S, Stoelben E, Philipp A, Bein T, et al. Extracorporeal membrane oxygenation: evolving epidemiology and mortality. Intensive Care Med. 2016;42:889. doi: 10.1007/s00134-016-4273-z.

31. Salvadèa I, Domenighettia G, Jollietb $P$, Maggiorinic M, Rothend HU. Perception of noninvasive ventilation in adult Swiss intensive care units. Swiss Med Wkly. 2012;142:1-8.

32. Jones SL, Devonald M. How acute kidney injury is investigated and managed in UK intensive care units - a survey of current practice. Nephrol Dial Transplant. 2013;28(5):1186-90. doi: 10.1093/ndt/gft015. 


\section{Sažetak \\ ZNAČENJE REGISTARA AKUTNE SKRBI KARDIOLOŠKIH BOLESNIKA NA NACIONALNOJ RAZINI}

\section{A. Đuzel, M. Pavlovi Z. Babić}

Unaprjeđenje organizacije i kvalitete skrbi o bolesnicima u jedinicama intenzivne skrbi postaje sve važnije zbog rastućeg opsega dostupnih metoda liječenja i skrbi. Suvremena literatura ukazuje na nedostatak odgovarajućih nacionalnih i internacionalnih registara. Cilj ovog istraživanja bio je analiza organizacije jedinica intenzivne kardijalne skrbi (JIKS) u Hrvatskoj i usporedba s ekonomski razvijenijim zemljama. Liječnici iz 34 hrvatske akutne bolnice (100\%-tni odgovor) ispunili su e-poštom poslan upitnik o organizaciji skrbi i metodama liječenja akutnih kardioloških bolesnika. Odgovori su prikupljeni i analizirani tijekom rujna i listopada 2016. godine. Hrvatska ima oko 5 JIKS na milijun stanovnika (raspon od 1 do 9, većinom 5-6 kreveta). Jedna medicinska sestra skrbi za prosječno 2,7 bolesnika (u jutarnjim satima za 2,3 bolesnika, u poslijepodnevnim satima 2,3 bolesnika, noću 3,3 bolesnika) uz varijabilnost ovisno o veličini bolnice (u manjim bolnicama prosječno za 2,9 bolesnika, u sveučilišnim bolnicama za 2,1 bolesnika, $\mathrm{p}<0,001$ ). Gotovo dvije trećine JIKS sadrži manje od 4 kreveta na jednog liječnika, dok kardiolozi čine 52\% liječnika tijekom radnog dana, ali samo 37\% liječnika tijekom dežurstva. Utvrdili smo značajnu varijabilnost u dostupnosti ultrazvuka srca tijekom radnog dana u odnosu na dežurstvo (76,5\% JIKS ima 24-satnu dostupnost transtorakalne ehokardiografije, ali samo $26,5 \%$ za transezofagusnu ehokardiografiju). Trećina ispitivanih centara nije uvela terapijsku hipotermiju, a 23,5\% centara ne radi izvantjelesnu membransku oksigenaciju niti premješta bolesnike u odgovarajuće ustanove. Organizacija i dostupne metode liječenja u JIKS ovise i o bruto društvenom proizvodu. Ovo istraživanje, prvo takve vrste u Republici Hrvatskoj, ukazuje na značajnu varijabilnost ključnih dijelova zdravstvene skrbi akutnih kardioloških bolesnika ovisno o veličini bolnice, ali i ukupni trend prema postojećim smjernicama. Ukazujući na prostor za napredak, ono može poslužiti kao polazna točka u postizanju željenog standarda, planiranju financija te procjeni i praćenju kvalitete nacionalnog zdravstvenog sustava.

Ključne riječi: Intenziuna kardiološka skrb; Kardiologija; Registar; Srce; Upitnik 